\title{
The Hanford Meteorological Data Collection System and Data Base
}

\author{
G. L. Andrews
}

April 1988

Prepared for the U.S. Department of Energy under Contract DE-AC06-76RLO 1830

Pacific Northwest Laboratory

Operated for the U.S. Department of Energy by Battelle Memorial Institute 


\section{DISCLAIMER}

This report was prepared as an account of work sponsored by an agency of the United States Government. Neither the United States Government nor any agency thereof, nor Battelle Memorial Institute, nor any or their employees, makes any warranty, expressed or implied, or assumes any legal liability or responsibility for the accuracy, completeness, or usefulness of any information, apparatus, product, or process disclosed, or represents that its use would not infringe privately owned rights. Reference herein to any specific commercial product, process, or service by trade name, trademark, manufacturer, or otherwise does not necessarily constitute or imply its endorsement, recommendation, or favoring by the United States Government or any agency thereof, or Battelle Memorial Institute. The views and opinions of authors expressed herein do not necessarily state or reflect those of the United States Government or any agency thereof, or Battelle Memorial Institute.

\section{PACIFIC NORTHWEST LABORATORY operated by \\ BATTELLE MEMORIAL INSTITUTE for the \\ UNITED STATES DEPARTMENT OF ENERGY under Contract DE-ACO6-76RLO 1830}

\begin{tabular}{|c|c|}
\hline \multicolumn{2}{|c|}{ Printed in the United States of America } \\
\hline \multirow{2}{*}{\multicolumn{2}{|c|}{$\begin{array}{l}\text { Available from } \\
\text { National Technical Information Service }\end{array}$}} \\
\hline & \\
\hline \multicolumn{2}{|c|}{$\begin{array}{l}\text { National Technical Information Service } \\
\text { United States Department of Commerce }\end{array}$} \\
\hline $\begin{array}{r}5285 \\
\text { Spring }\end{array}$ & 22161 \\
\hline \multirow{2}{*}{\multicolumn{2}{|c|}{$\begin{array}{l}\text { NTIS Price Codes } \\
\text { Microfiche A01 }\end{array}$}} \\
\hline & \\
\hline \multicolumn{2}{|c|}{ Printed Copy } \\
\hline & Price \\
\hline Pages. & Codes \\
\hline $001-025$ & A02 \\
\hline 026-050 & $\mathrm{A} 03$ \\
\hline $051-075$ & A04 \\
\hline 076-100 & A05 \\
\hline $101-125$ & A06 \\
\hline $126-150$ & A07 \\
\hline 151-175 & A08 \\
\hline $176-200$ & $A 09$ \\
\hline $201-225$ & A010 \\
\hline $226-250$ & A011 \\
\hline $251-275$ & A012 \\
\hline $276-300$ & $\wedge 013$ \\
\hline
\end{tabular}


THE HANFORD METEOROLOGICAL DATA COLLECTION SYSTEM AND DATA BASE

G. L. Andrews

April 1988

Prepared for the U.S. Department of Energy under Contract DE-AC06-76RLO 1830

Pacific Northwest Laboratory

Richland, Washington 99352 


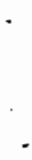


The Hanford Meteorological Station (HMS), operated by Pacific Northwest Laboratory (PNL), provides meteorological and climatological services to the Department of Energy in Richland and its contractors. On a 24-hour basis, the HMS measures, records, and archives meteorological data collected hourly throughout the year. The current data base consists of five components:

- wind telemetry stations

- doppler acoustic sounders (SODAR)

- 200-ft towers

- 410-ft tower at the HMS

- surface weather observations at the HMS.

The wind telemetry station data, 410-ft tower data, and surface weather observation data are permanently archived into yearly ACSII files, and the remaining components are permanently archived in binary form on magnetic tape. The future data base will consist of the same five components, but all components will be permanently archived into yearly ASCII files.

Quality assurance computer programs will be written to validate the current data base, and a data archival program will be written to improve the archival method that is currently used. 



\section{ACKNOWLEDGMENTS}

The author would like to thank the staff at the Hanford Meteorological Station for their assistance during the preparation of this document. Special thanks to Dana Hoitink, the HMS project manager, for his continued support and Ora Gifford for his helpful suggestions and ideas. 



\section{CONTENTS}

SUMMARY . • . . . . . . . .

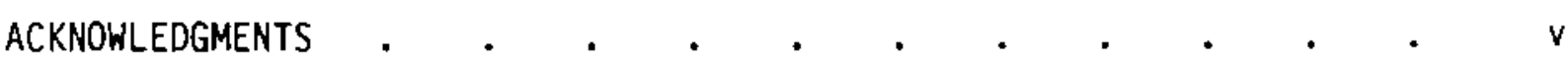

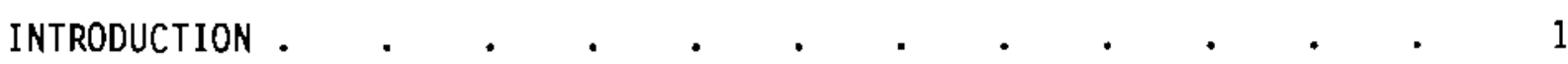

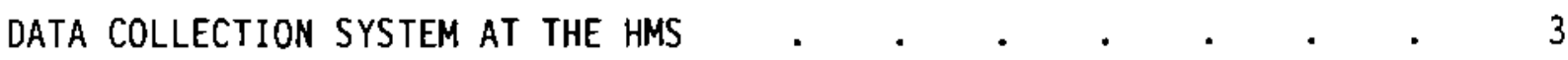
DESCRIPTION OF THE CURRENT DATA COLLECTION SYSTEM . $\quad$ • $\quad$ • 4 SENSORS FOR MEASURING METEOROLOGICAL VARIABLES . • • • $\quad$ • 5

CURRENT DATA BASE AT THE HMS $\quad$ •

SURFACE WEATHER OBSERVATION DATA • • • • • • • . 7

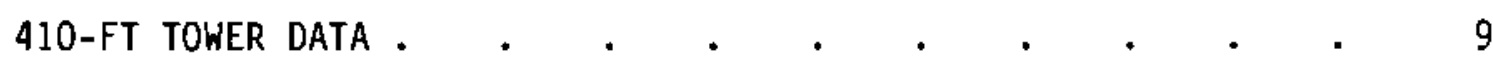

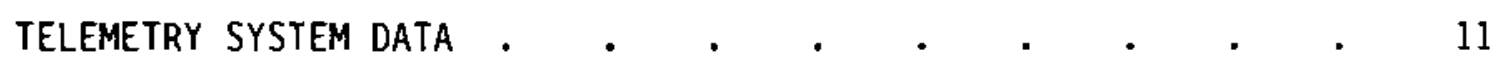

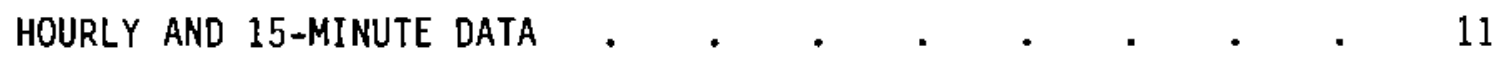

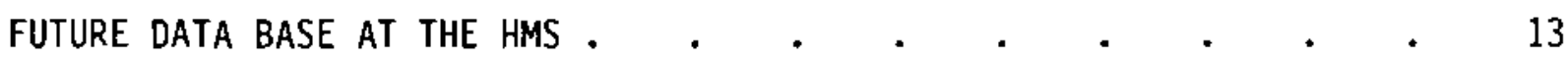

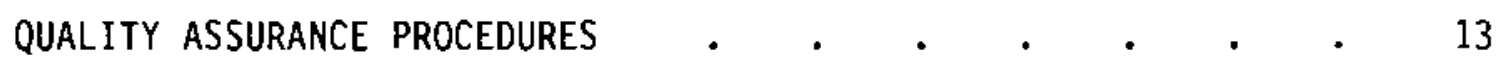

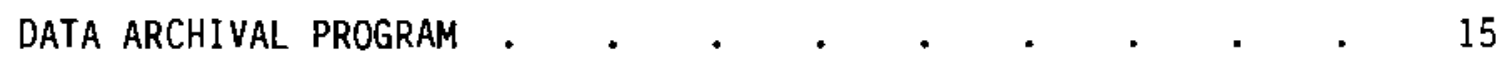

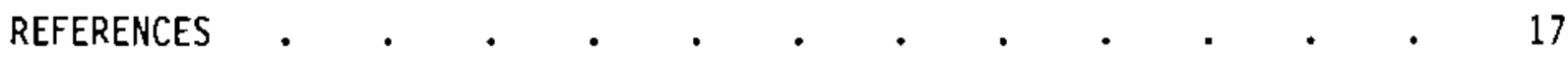

APPENDIX A - DESCRIPTION OF THE HOURLY AND 15-MINUTE DAILY FILE FORMATS A.1 APPENDIX B - SENSORS LISTING AND IDENTIFICATION • . • • • • B.1 



\section{INTRODUCTION}

The Hanford Meteorological Station (HMS), operated by the Pacific Northwest Laboratory (PNL) for the U.S. Department of Energy in Richland, Washington, collects, measures, and archives meteorological data each hour throughout the year. The HMS is located in the northwest quadrant of the Hanford Site, approximately 1/2-mile east of the 200-West (200W) Area (Fig. 1). Hanford contractors and outside agencies use the data for a variety of applications (e.g., engineers at the Hanford Site use HMS data for engineering applications, such as calculating heating and cooling loads).

This report describes the contents, implementation, and location of the current data base and the future data base at the HMS. The history of the data collection system at the HMS and a current inventory of measured variables are also addressed, and plans for future archival and retrieval programs are identified. Detailed discussions of the data entry codes used for archival have been presented previously (Buck and Andrews 1987a, b, c; Andrews and Buck 1987a, b, c). Discussions in this report consider only the meteorological data collected and archived by the HMS; a forthcoming PNL report will discuss and describe the data collection system in more detail. 


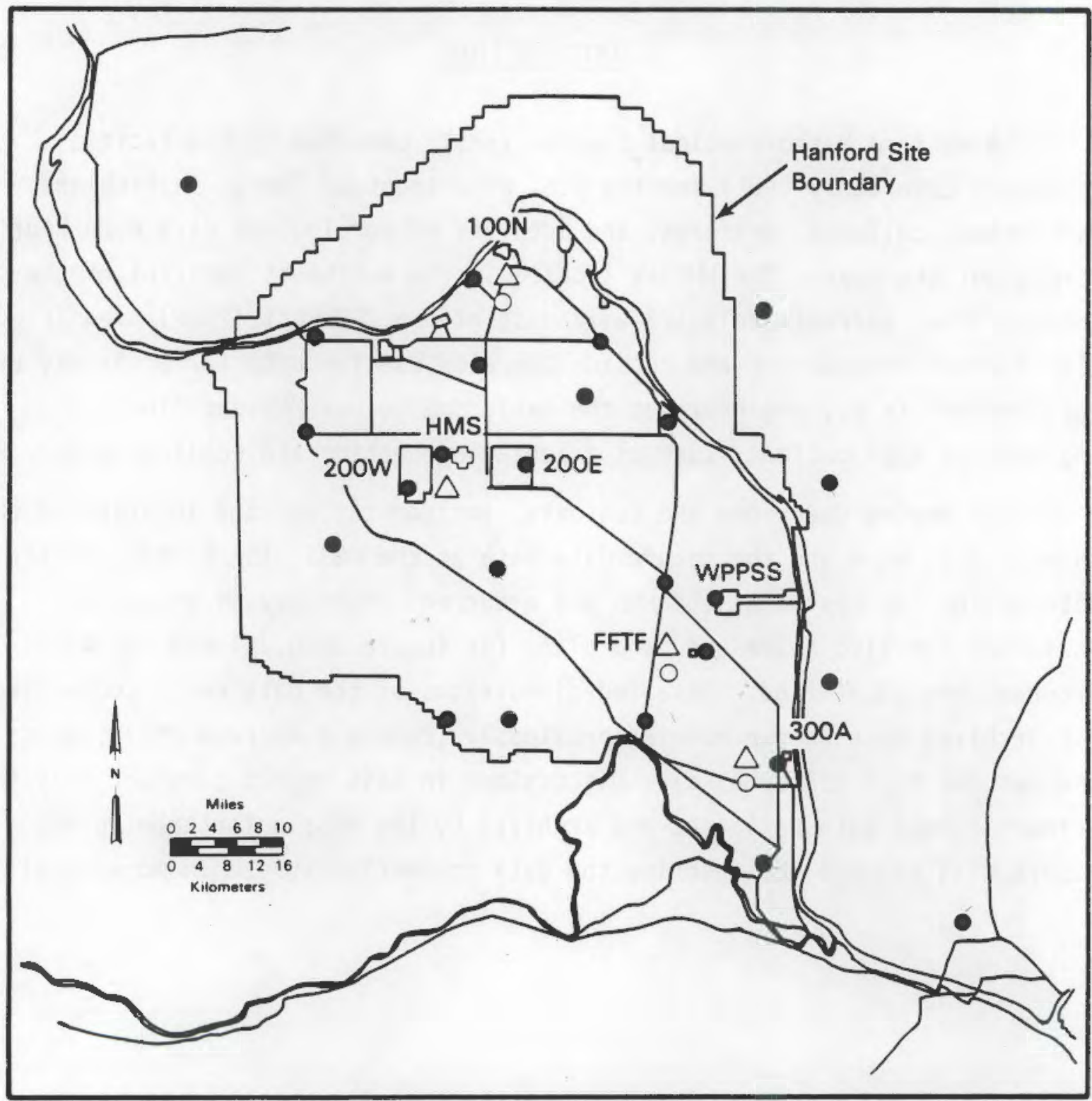

- Telemetry Locations

$\triangle$ SODAR Locations

O 200-ft Tower Locations

$410-\mathrm{ft}$ Tower and

Surface Observation Location

Figure 1. Distribution of the Data Collection Components on the Hanford Site 


\section{DATA COLLECTION SYSTEM AT THE HMS}

The meteorological data collection system currently used at the HMS measures, records, and archives meteorological data on an hourly and 15minute basis. As used here, the phrase "data collection system" refers to all phases of the data collection process, from the use of sensors for measuring meteorological variables to methods for archiving the data on weather forms or on the DEC VAX 11/750 computer at the HMS. "Data base" refers to the product generated by the data collection system (i.e., monthly and daily files that contain the HMS meteorological data).

The HMS was built in 1944 along with a $410-\mathrm{ft}$ meteorological tower approximately $1 / 2-m i l e$ east of the $200 \mathrm{~W}$ Area (see Fig. 1). At that time the data collection system consisted mainly of surface weather observations and data from several levels of the tower. The forecaster manually recorded and archived these data on weather forms. This system was used until the late 1970 s when wind telemetry stations, placed at various locations on and off the Hanford Site, were added to the data collection system. The wind telemetry information was sent via radiowave to a computer (PDP 1108) at the HMS, where each hour the data were archived on magnetic tape. For permanent archival, these data were also manually recorded on weather forms. The forms are stored at the HMS library and can be checked out by contacting Ora Gifford (509/373-3216) or one of the on-duty forecasters.

In late 1985, the data collection system was again expanded to include the Emergency Response Detection System (ERDS) [now called the Emergency Management System (EMS)]. The EMS was established to provide emergency response capabilities for the Hanford Site, and is capable of handling data associated with toxic and/or radionuclide releases to the atmosphere and ground. This addition significantly increased the capabilities of the HMS data collection system. The following equipment and sensors were added:

- three 200-ft instrumented towers

- four doppler acoustic sounders

- 10 wind telemetry stations

- a Digital Equipment Corporation VAX 11/750 computer

- interfaces for transferring data to the VAX $11 / 750$. 
Programs that run on the HMS computer gather and organize the meteorological data into two data bases, one that contains hourly averages and one that contains 15 -minute averages. The following is a more detailed description of the current data collection system.

\section{DESCRIPTION OF THE CURRENT DATA COLLECTION SYSTEM}

The current HMS data collection system consists of wind telemetry stations, doppler acoustic sounders (SODAR), 200-ft towers, the $410-\mathrm{ft}$ tower at the HMS, and surface weather observations at the HMS. Figure 1 shows the distribution of these components within and near the Hanford Site. Within these components are instrumentation and sensors that measure, collect, and archive several meteorological variables:

- wind direction and speed (average, maximum, and minimum)

- sigma theta and sigma wind speed

- temperature difference between $60-\mathrm{m}$ and $10-\mathrm{m}$ (delta-temperature)

- dry bulb temperature (average, maximum, and minimum)

- dew point temperature

- atmospheric pressure

- precipitation

- solar radiation.

Currently, two methods are used to archive the meteorological data collected. For one method the forecaster manually records the data each hour on weather forms; for the other method the HMS computer automatically archives the data every hour and every 15 minutes. Table 1 indicates the archival method for each component of the data collection system. Eventually only the computer will be used to archive the data collected from the wind telemetry stations and the $410-\mathrm{ft}$ tower.

For archiving data collected from the wind telemetry stations, $410-\mathrm{ft}$ tower, and surface weather observations, the forecasters use data entry programs to transfer the data to the HMS computer. (The following section of this report describes the location of the files produced by the data entry codes and the file name convention). Computer-archived meteorological data are collected via microwave or dedicated line and 
TABLE 1. Archival Method for Data Collected

\begin{tabular}{ll}
\multicolumn{1}{c}{ Component } & Method of Archive \\
\cline { 2 - 2 } Wind telemetry stations & Manual and computer \\
Doppler acoustic sounders & Computer \\
$200-\mathrm{ft}$ towers & Computer \\
$410-\mathrm{ft}$ tower & Manual and computer \\
Surface weather observations & Manual
\end{tabular}

archived on the appropriate HMS computer data base in 15-minute and hourly intervals. Each data base consists of daily files. The hourly daily files contain 24 hours of meteorological data and the 15-minute daily files contain 96 ( $24 \times 4) 15$-minute periods of data. Each hour in the daily files is divided into two blocks of data. Appendix A contains a detailed description of the hourly and 15-minute daily file formats.

SENSORS FOR MEASURING METEOROLOGICAL VARIABLES

Approximately 400 meteorological variables are measured by the HMS data collection system, and each variable is assigned a sensor identification (ID). Appendix B contains a list of those IDs. The list may be increased as more variables are added to the data collection system. Sensor IDs are used in data retrieval programs (e.g., the program GET_EMS.FOR) to access specific data. Additional IDs will be needed in programs being developed for collecting and storing specific data. 



\section{CURRENT DATA BASE AT THE HMS}

The HMS database that is currently being used consists of four components:

- surface weather observations

- 410-ft tower data

- telemetry system data

- 15-minute and hourly data (these data are automatically collected by the HMS computers).

Data for the first three components are kept on separate disk packs at the HMS that are identified SFCOBS for the surface weather observations, TOWER for the $410-\mathrm{ft}$ tower data, and TELEM for the wind telemetry data.

Each disk pack contains yearly files of the indicated data in ASCII format, with 80 characters per record. Data are also available in handwritten form at the HMS library. The 15-minute and hourly data are kept on the system disk (DUAO:).

\section{SURFACE WEATHER OBSERVATION DATA}

Data from surface weather observations represent a variety of weather information such as cloud cover, cloud type, dry bulb temperature, wet bulb temperature, relative humidity, and atmospheric station pressure. Figure 2 is a copy of the surface weather observation form that the forecasters complete each hour. The weather variables that the forecaster records are indicated at the top of the form. Although surface weather observations exist in handwritten form from the present time back through 1944, the computer files for the surface weather observations cover the period from 1955 through the present. The computer code SFC (Andrews and Buck 1987c) is used to enter data for surface weather observations into the HMS computer. These data are stored in the [FCST.DAT] subdirectory in monthly files. The convention used in naming the monthly files is SFCOBSxxx.DAT, where $x x x$ is the three-character abbreviation of the current month (e.g., AUG August). At the end of each year, the monthly files are consolidated into a yearly file (e.g., SFCOBS87.DAT) that is placed on the SFCOBS disk pack located in the forecast room at the HMS. 
80 1800175612021

\begin{tabular}{|c|c|c|c|c|c|c|c|c|c|c|c|c|c|c|c|c|c|c|c|c|c|c|c|c|c|c|c|}
\hline \multicolumn{28}{|c|}{ HANFORD SURFACE DBSERVATIONS } \\
\hline \multirow[b]{2}{*}{ clovios } & \multicolumn{3}{|c|}{ DATE } & \multirow[b]{2}{*}{$\begin{array}{l}\frac{\alpha}{5} \\
\frac{0}{x}\end{array}$} & \multirow{2}{*}{ 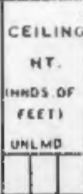 } & \multirow{2}{*}{ 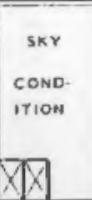 } & \multirow[b]{2}{*}{ 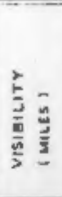 } & \multicolumn{3}{|c|}{$\begin{array}{l}\text { WEATHER AND OA } \\
\text { OQSIE TO VISION }\end{array}$} & \multirow{2}{*}{$\begin{array}{l}\text { SEA. } \\
\text { LEVEL } \\
\text { PAESS- } \\
\text { URE } \\
\text { ( MOS I }\end{array}$} & \multirow[b]{2}{*}{\begin{tabular}{|l|} 
OEW \\
POIN \\
OOFI \\
- \\
\end{tabular}} & \multicolumn{2}{|c|}{ mIND } & \multirow[b]{2}{*}{$\begin{array}{c}\text { STATION } \\
\text { PRESS. } \\
\text { (INEMESI }\end{array}$} & \multirow[b]{2}{*}{$\begin{array}{l}\text { DRY } \\
\text { BULE } \\
-^{\text {OF }}\end{array}$} & \multirow[b]{2}{*}{$\begin{array}{c}\text { WET } \\
\text { BULE } \\
Z^{\text {OF }}\end{array}$} & \multirow[b]{2}{*}{$\begin{array}{l}\text { PEL } \\
\text { HUM. } \\
1 \therefore 1\end{array}$} & \multirow[b]{2}{*}{ 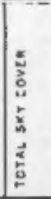 } & \multirow[b]{2}{*}{ 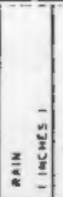 } & \multirow[b]{2}{*}{ | } & \multirow[b]{2}{*}{ 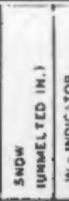 } & \multirow[b]{2}{*}{ 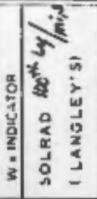 } & \multicolumn{3}{|c|}{ COLUMAIA RIVER } & \\
\hline & $\stackrel{\alpha}{\alpha}$ & 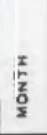 & à & & & & & 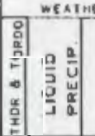 & 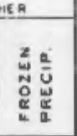 & 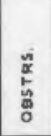 & & & $\begin{array}{l}\frac{0}{2} \\
\frac{\alpha}{6}\end{array}$ & & & & & & & & & & & $\begin{array}{l}\text { ELEV } \\
\text { (FtET) }\end{array}$ & $\begin{array}{l}\text { TEMP } \\
\text { TOCI }\end{array}$ & $\begin{array}{l}\text { FLow } \\
\text { Icrst }\end{array}$ & \\
\hline 1,1 & $\perp$ & 4 & - & 0,1 & 11 & -111 & $-L L$ & -1 & -11 & -1 & 12,1 & $-1,1$ & 3 & 1 & 11 & 一ᄂ. & 1, & {$\left[\begin{array}{ll}3 & 53 \\
-1 & 1\end{array}\right.$} & 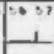 & & 11 & 1 & 86 & 1,1 & $\begin{array}{l}73 \quad{ }^{73} \\
1 \quad 1 \\
\end{array}$ & 1,17 & \\
\hline $1,1,1$ & $\perp$ & 2 & 1 & 0,2 & 1, & $1 L_{1}$ & 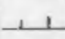 & 1 & -1.1 & - L & 1,1, & 1,1 & בـ & -1 & ــــ & $-1,1$ & 1_ I & -11. & $-1-$ & -1. & إ & 1. & , & $-1,1$ & 1, & 1,1 & \\
\hline+11 & -1 & _L & 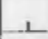 & 0,3 & 1, & 111 & 1.1 & -1 & $-L \perp$ & 1 & $\perp \perp \perp$ & -1, & 1 & 1. & 1,1 & I-L & -1.1 & 1.1 & 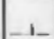 & -1. & 1 & 1 & 1 & 1 & & & \\
\hline $1,1,1$ & 1 & $\perp$ & 1 & 0,4 & $\perp \perp$ & $-1,1$ & 11 & 1 & 1 & 1 & -111 & 11 & -1. & 1 & 111 & 11 & 11 & 11 & & 1 & $\perp$ & 1 & 1, &, 1, & 1 & 1 & \\
\hline $1,1,1$ & 1 & 1 & & 0,5 & 11 & 11, & 1.1 & 1 & 1, & 1 & 1,1 & 1,1 & 1 & -1 & $\perp L L$ &, &, 1 & 1 & & 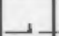 & $L_{1}$ & , & & 1 & 1 & 1,1 & \\
\hline 1,1, & $\perp$ & 1 & 1 & 0 典 & 11 & 1.11 & 1 & $\perp$ & 1 & 1 & 1,1 & 1,1 & -1 & -1 & 1 & 1,1 & 12 & +1 & & ] & 1 & 1 & & & & & \\
\hline 1111 & 1 & 1 & -1 & 0,7 & $1-1$ & 111 & 11 & 1 & -1.1 & , & 1.1. & 11 & 1 & 1 & $1 / 1$ & -1, & -1, & 1,1 & & $1-1$ & 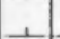 & 1 & & 11 & 11 & $1 \mathrm{I} 1$ & \\
\hline & 1 & -1 & & 0,8 & $\perp 1$ & 111 & 11 & 1 & -11 & 1 & 111 & 1 & 1 & 1 & 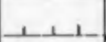 & -1 & 11 & & & & 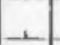 & 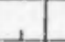 & & & 1, & & \\
\hline 1,1 & 1 & I & 1 & $0 \_9$ & 11 & $1,1$. & 11 & -1 & (1ـ & + & 112 & , &, & 1 & $-1-1$ & 1, & 1,1 & 11 & & -1 . & 1 & 1 & & 1.1, & 1, & 1 & \\
\hline 1 & 1 & -1 & 1 & 1,0 & 11 & 111 & $1+$ & 1 & 1 & 1 & 111 & 1 & 1 & 1 & $I_{1}$ & 1 & +1 & 1 & & $1-$ & 1 & 1 & & & & & \\
\hline $1+11$ & 1 & $\perp$ & + & 1,1 & 11 & 1.11 & 11 & 1 & $1.1+$ & - - & -t._L_t & 11 & -1 & 1 & - L $1-1$ & $-1,1$ & 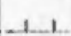 & 1 - & 1 & -1. & -1 & 1 & 1 & $1+1$ & -1 & 1 & \\
\hline 1,111 & $\perp$ & 1 & -1 & 1.3 & $\perp 1$ & 1 & 1.1. & $\perp$ & 1 & 1 & 1,1 & 11 & 1. & 1. & $L 11$ & 1. & 1,1 & 1 & 1 & $\ldots$ & -1 & 1 & 1. & 1,1 & $-1,1$ & 111 & \\
\hline $1,1,1$ & 1 & 1 & -1 & 1.4 & 11 & 111 & 1,1 & 1 & 11 & 1 & 1,1 & -11 & 1 & 1 & 111 & 1 & 1 & 1,1 & 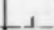 & 1 & + & 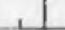 & 1 & 1,1 & $\mathrm{Lt}$ & 1 & \\
\hline $1+\mathrm{t}$ & -1 & + & $-1>>3$ & 1,5 & 1 & 1,1 & 1, & 1 & 1 & 1 & , & 1, & 1 & -1 & 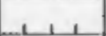 & 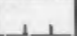 & 1 & tat & & $1-$ & $I_{-}-1$ & & t & 11 & 1 & 1,1 & \\
\hline $1+11$ & -1 & 1 & 1 & 1,6 & 11 & 1 & 1.1 & $L$ & I. 1 & LL & $1<1$ & 11 & 1 & 1 & LLLL & -11 & 11 & 1,1 & 1. & - & 1 & 1 & $1+$ & 1, & $1+1$ & 1,1 & \\
\hline$L_{1} L_{1}$ & $\perp$ & 1 & 1 & 1,7 & 1. & . 1ـ1. & $1+1$ & $L$ & 11 & 1 & LLt & .1 & 1 & 1 & 1 & +1.1. & 11 & & & 1. & , & , & 1, & 11 & 1 & $1+1$ & \\
\hline $1,1,1$ & -1 & 1 & 1 & 1,8 & $\perp 1$ & 1,1 & 11 & 1 & $\perp 1$ & $-\perp$ & 111 & -1 & -1 & -1. & I_LL & 11 & 11 & 1,1 & ]$_{-}$ & ــ & 1. & L & -11 & 111 & 11 & 1,1 & \\
\hline 1,1 & 1 & 1 & -1 & 1,9 & 1. & 1,1 & 1, & ــ & 1,1 & 1 & $\perp<1$. & 1, & 1 & i & $-1,1$ &. & I_L & -1.1. & -1. & . & -1. & 1 & 1.1. & 111 & 1, & 1 & \\
\hline 1,1 & $\perp$ & -1. & -1 & 20 & I_L & $1 \ldots 1$ & L 1 & 1 & 11 & 1 & 1,1 & 11 & . & 1. & L & 11 & 1,1 & 1, & 1 & $1-2+2$ & 1 & 1 & 1, & 1 & 1 & 1,1 & \\
\hline டレしーட & 1 & $L$ & 1 & $2 \perp$ & 11 & $1 \perp 1$ & 11 & 1 &, 1 & ـ. & 1,1 & 11 & 1 & -1 & 111 & $1 \perp$ & 11 & 11 & 1 & ـــ ــ & -4 & 1 & 1. & 11, & 11 & $.1,1$ & \\
\hline 1111 & 1 & 1 & & $21^{2}$ & $\perp$. & 111 & 1, & 1 & 1, & & 1,1 & 1,1 & 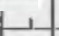 & 1 & 11.1 & -11 & $1-1$ & -1. & & A... & L- & I & 1 & & 1 & 1 & \\
\hline 1,1 & + & -1 & & 2,3 & 11 & $1 \perp$ & 1.1 & 1 & $1-1$ & -1 & 1.1 & -11 & -1 & 1 & $1-1$ & $-1,1$ & 11 & $-1-1$ & -1. & - - & 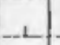 & 1 & -1 & LILL & 1 & 1,1 & \\
\hline $1,1,1$ & 1 & 1 & LL. & 2.4 & {$\left[\begin{array}{ll}1 & 1\end{array}\right.$} & 111 & $\therefore 1$ & D. & 1.1 & $|\perp|$ & 1,11 & 1, & $|1|$ & إ_ & 1,1 & $\ldots 1$ & 1.1 & $1 L_{1}$ & & & & & & & & & \\
\hline
\end{tabular}

FIGURE 2. Example of the Hourly Surface Observation Form 
In FY 1986 quality assurance programs were run on each year of the surface weather observation data to correct errors and identify missing data. The programs identified numerous missing variables and some systematic errors that are being corrected.

\section{0-FT TOWER DATA}

Data from the $410-\mathrm{ft}$ tower consist of wind and temperature information from various levels of the tower. Figure 3 is a copy of the form used by the forecasters to record the data. The data, which are recorded hourly, are obtained from strip charts located in the HMS forecast room. The weather variables that the forecaster records are indicated at the top of the form (negative signs indicate below-ground measurements). Although data for the 410-ft tower exist in handwritten form from the present back through 1944, the computer files for the surface weather observation cover the period from 1955 through the present. The forecasters use the computer code TOWER (Buck and Andrews 1987c) to archive the $410-\mathrm{ft}$ tower information on the HMS computer. These data are stored in the [FCST.DAT] subdirectory in monthly files. The convention used in naming the monthly files is TOWERxxx.DAT, where $x x x$ is the three-character abbreviation of the current month (e.g., AUG August). At the end of each year, the monthly files are consolidated into a yearly file (e.g., TOWER87.DAT) that is placed on the TOWER disk pack located in the forecast room at the HMS.

These data are also automatically archived by the HMS computer every hour and at 15-minute intervals. Until programs are written to check the quality assurance of that data, forecasters will continue to use the computer code TOWER to archive the data on the HMS computer.

The data for the $410-\mathrm{ft}$ tower has also been reviewed by quality assurance programs; however, the amount of errors and missing data is not so extensive. The errors and missing data will be corrected. 
HANFORD TEMPERATURE AND WIND DATA

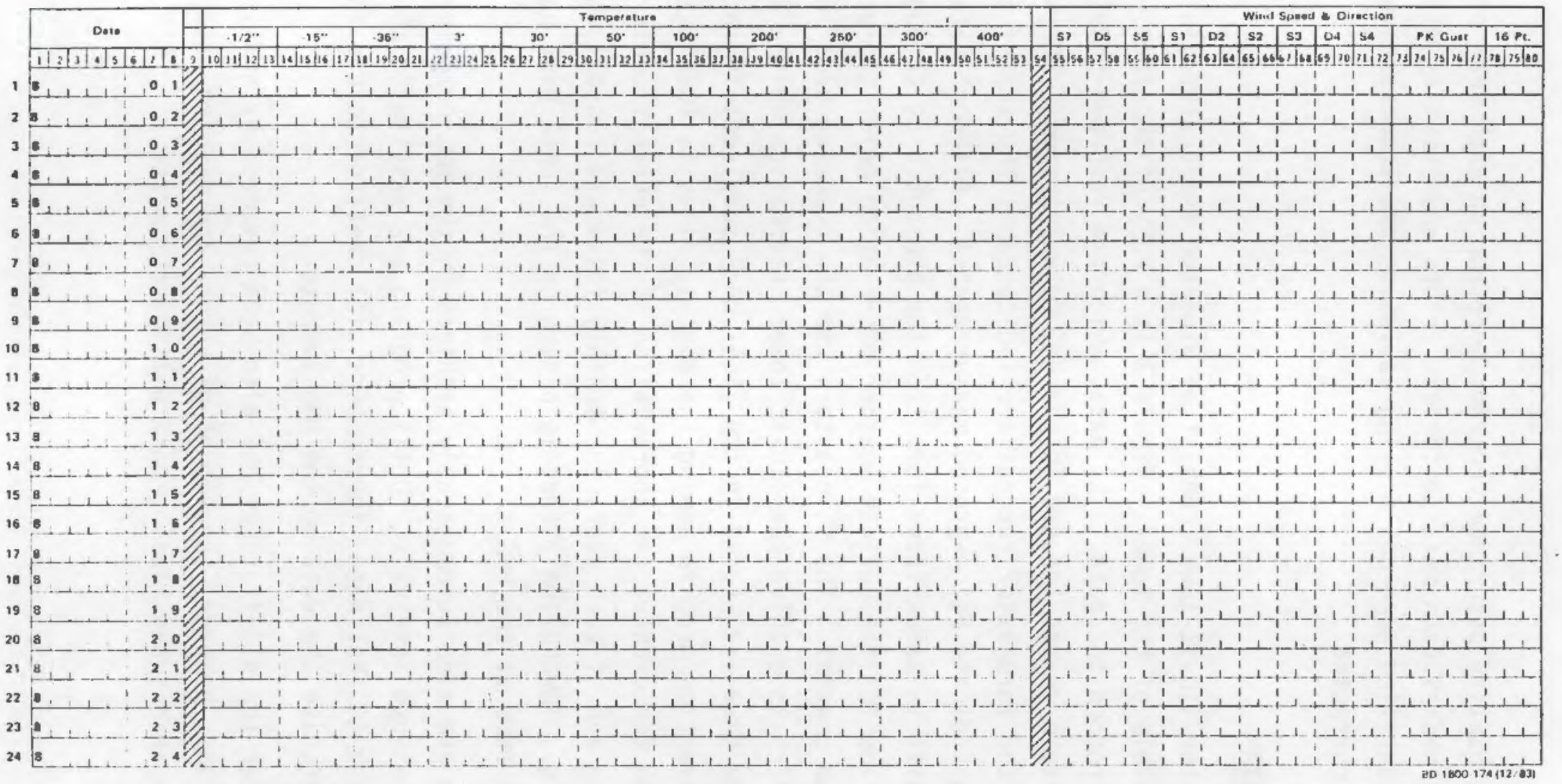

S7 - Speed Al 7 Feet

D5 - Wind Direction At 50 feet

S5 $=$ Speed At 50 Feet

Exc.

sion nanewant

FIGURE 3. Example of the Hourly Tower Form 


\section{TELEMETRY SYSTEM DATA}

The data from the wind telemetry system contain wind speed and wind direction information from a network of $33-\mathrm{ft}(10-\mathrm{m})$ wind towers (see Fig. 1). Atmospheric stability and mixing level are included with the wind telemetry data. The computer code UPDATE (Athey, Allwine and Ramsdell 1981) is used by the forecasters each hour to enter the wind telemetry data on the HMS computer. These data are stored in the [FCST.DAT] subdirectory in monthly files. The convention used in naming the monthly files is TELEMxxx.DAT, where $x x x$ is the three-character abbreviation of the current month (e.g., AUG August). At the end of each year, the monthly files are consolidated into a yearly file (e.g., TELEMB7.DAT) and placed on the TELEM disk pack located in the forecast room at the HMS.

Quality assurance programs have not yet been run on the wind telemetry data. However, quality assurance codes will be run on the data and erroneous data will be corrected.

HOURLY AND 15-MINUTE DATA

Hourly and 15-minute data are automatically collected by the HMS computer. The data are stored in two separate data bases, as described previously. Both of the data bases are in binary form. Each month the hourly data base is backed-up on magnetic tapes that are stored permanently at the HMS.

Currently, the hourly and 15-minute data bases are not converted to ASCII format or grouped into similar data groups. However, the future data base will include such a conversion. 

The data base that will be developed for the HMS will incorporate the current data base and data from the 15-minute and hourly data bases. The future data base will have five components:

- wind telemetry data

- doppler acoustic sounders (SODAR) data

- 200-ft tower data

- 410-ft tower data

- surface weather observations data.

Data from the first four components will be acquired automatically from the hourly data base. The surface weather observations will continue to be archived by the forecasters and entered on the HMS computer using the SFC program. Data will be stored on disk packs in yearly files. The directory structure for each disk pack is shown in Figure 4. The files will be in ASCII format with 80 characters per record.

The directory labelled MISCELLANEOUS will contain forecast data, pilot balloon (PIBAL) data, and daily summary information. The forecast and daily summary data will be accumulated from the data entry codes, as previously discussed. The PIBAL data will be accumulated from the pilot balloon that is released twice a day (1200 PST and 2400 PST) at the HMS.

\section{QUALITY ASSURANCE PROCEDURES}

Two levels of quality assurance will be applied to the future data base. The first level will check for gross errors in the data as it is archived to monthly files. For example, wind direction will be checked to make sure it is within the range of 0 through 360 . The second level of quality assurance will be applied each month and will provide a more rigorous check. For example, the temperature will be compared with the climatological limits for the particular month, and hour-by-hour comparisons will be made to flag large jumps $\left(10^{\circ} \mathrm{F}\right)$ in the temperature. 


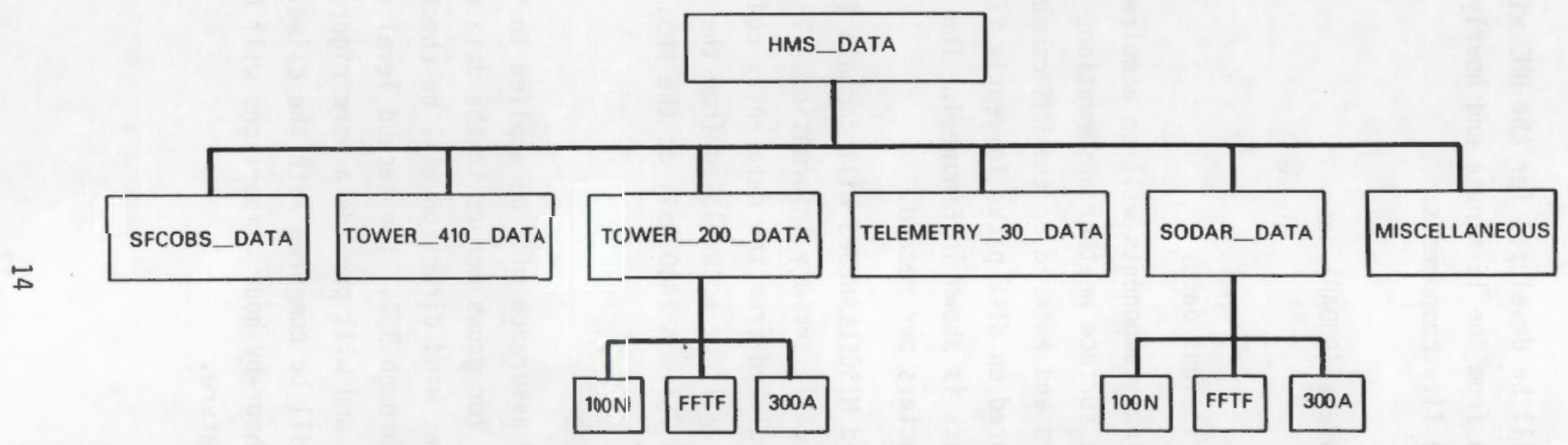

Figure 4. Directory Structure of the Future Data Base 


\section{DATA ARCHIVAL PROGRAM}

The data archival program will be submitted by a batch job on a daily basis, probably after midnight. The program will organize data into components (see Fig. 4) and perform gross error checks. It will then store information in monthly files on removable disk packs. These disk packs will be stored at the HMS. 


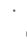




\section{REFERENCES}

Andrews, G.L. and J.W. Buck. 1987a. Hanford Meteorological Station Computer Codes Volume 2 - The PROD Computer Code. PNL-6279 Vol. 2, Pacific Northwest Laboratory, Richland, Washington.

Andrews, G.L. and J.W. Buck. 1987b. Hanford Meteorological Station Computer Codes Volume 4 - The SUM Computer Code. PNL-6279 Vol. 4, Pacific Northwest Laboratory, Richland, Washington.

Andrews, G.L. and J.W. Buck. 1987c. Hanford Meteorological Station Computer Codes Volume 6 - The SFC Computer Code. PNL-6279 Vol. 6, Pacific Northwest Laboratory, Richland, Washington.

Athey, G.F., K.J. Allwine, and J.V. Ramsdell. 1981. User's Guide to the MESOI Diffusion Model and to the Utility Programs UPDATE and LOGRVU. PNL-3999, Pacific Northwest Laboratory, Richland, Washington.

Buck, J.W. and G.L. Andrews. 1987a. Hanford Meteorological Station Computer Codes Volume 1 - The GEN Computer Code. PNL-6279 Vol. 1, Pacific Northwest Laboratory, Richland, Washington.

Buck, J.W. and G.L. Andrews. 1987b. Hanford Meteorological Station Computer Codes Volume 3 - The TANK Computer Code. PNL-6279 Vol. 3, Pacific Northwest Laboratory, Richland, Washington.

Buck, J.W. and G.L. Andrews. 1987c. Hanford Meteorological Station Computer Codes Volume 5 - The TOWER Computer Code. PNL-6279 Vol. 5, Pacific Northwest Laboratory, Richland, Washington. 


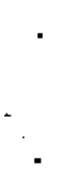

. 


\section{APPENDIX A}

DESCRIPTION OF THE HOURLY AND 15-MINUTE DAILY FILE FORMATS 
APPENDIX A

\section{DESCRIPTION OF THE HOURLY AND 15-MINUTE DAILY FILE FORMATS}

Hourly and 15-minute daily files contain 24 hours of meteorological data. These files are structured identically. Each hour is divided into two blocks of data. Figure A.1 shows an example of one block of data. Each block of data begins with a header containing the date, hour, minute, number of sensor identifications (IDS), and a list of the sensor IDs. The header is then followed by the data associated with the sensors listed in the header. Each record of data contains a record number, internal ID, alpha/numeric description, mean value, standard deviation, and number of samples. The 15minute files are structured in the same manner except there are ninety-six 15 -minute periods of information.

The hourly and 15-minute daily files have unique filename extensions. The 15-minute daily files are identified by the .QLG filename extension and the hourly daily files are identified by the. HLG extension. The 15-minute database is stored in the [ERDSSYS.DAT.MESORAD.INPUT] subdirectory and the hourly database is stored in the [ERDSSYS.DAT.SENSORS] subdirectory. The current day hourly data base is kept in the [ERDSSYS.DAT.SENSORS] subdirectory.

A program called DEBUG resides in each database directory. DEBUG allows the user to view the contents of a daily file from either the 15-minute or hourly database. Invoke the program by typing DEBUG and depressing the RETURN key. Answer the questions as they appear on the screen. Depress the CTRL and $Y$ key simultaneousiy to exit DEBUG. 


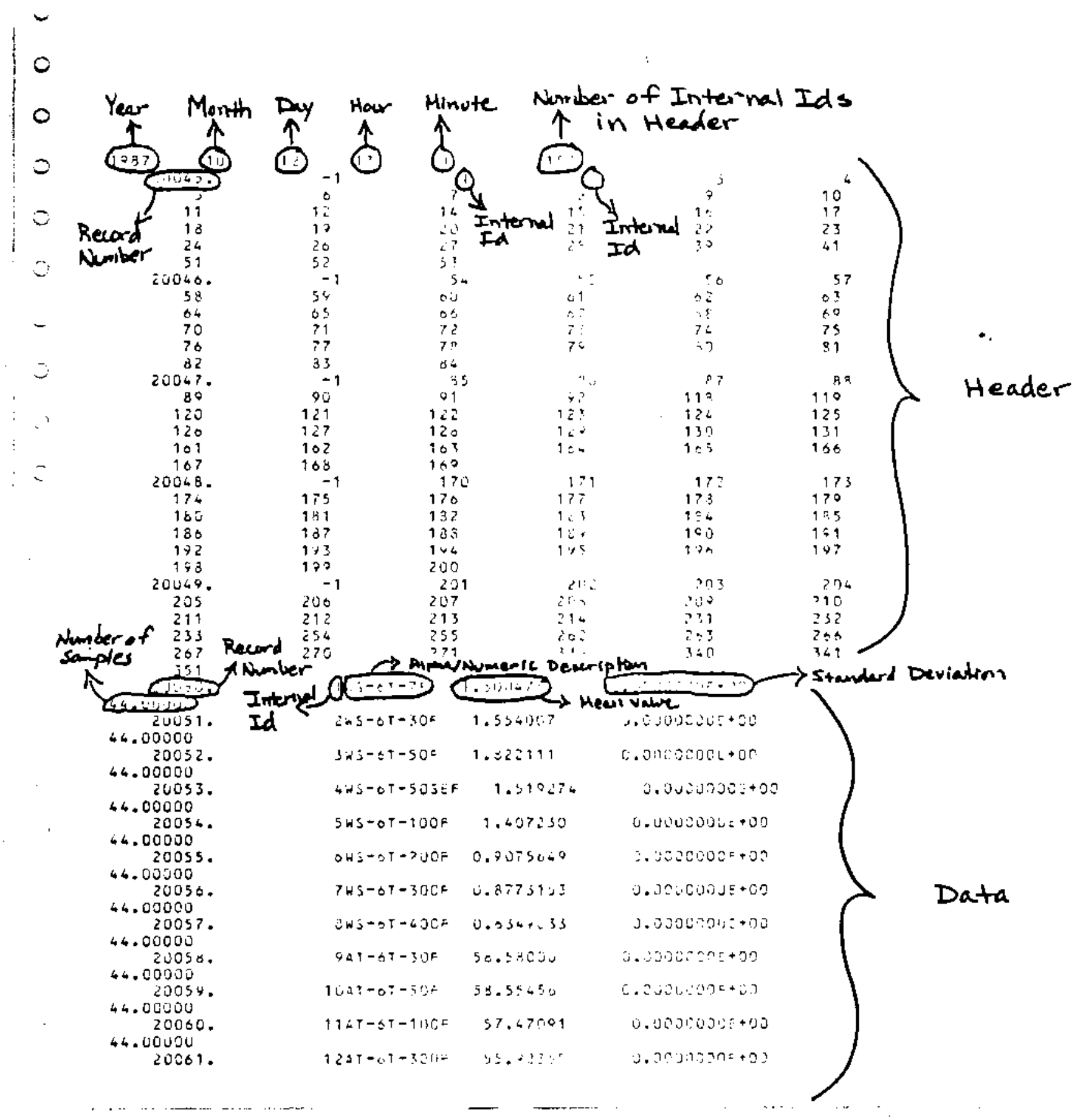


APPENDIX B

SENSORS LISTING AND IDENTIFICATION 
KEY TO ABBREVIATIONS IN THE ALPHA/NUMERIC IDENTIFICATION

\begin{tabular}{|c|c|}
\hline Abbreviation & Description \\
\hline $300 \mathrm{~A}$ & 300 Area \\
\hline $7 \mathrm{~F}$ & 7 Foot Level \\
\hline $30 \mathrm{~F}$ & 30 Foot Level \\
\hline $50 \mathrm{~F}$ & 50 Foot Level \\
\hline 50SEF & $\begin{array}{l}50 \text { Foot Level Southeast } \\
\text { Corner of } 410-\mathrm{ft} \text { Tower }\end{array}$ \\
\hline $100 \mathrm{~F}$ & 100 Foot Level or $100 \mathrm{~F}$ Area \\
\hline $200 \mathrm{~F}$ & 200 Foot Level \\
\hline $250 \mathrm{~F}$ & 250 Foot Level \\
\hline $300 \mathrm{~F}$ & 300 Foot Level \\
\hline $400 \mathrm{~F}$ & 400 Foot Level \\
\hline 10 & 100 Area Doppler $(100 \mathrm{~N})$ \\
\hline 30 & 300 Area Doppler \\
\hline 40 & 400 Area Doppler (FFTF) \\
\hline 60 & 600 Area Doppler (HMS) \\
\hline $200 E$ & 200 East Area \\
\hline $2 M$ & 2 Meter Level \\
\hline $10 \mathrm{M}$ & 10 Meter Level \\
\hline $25 \mathrm{M}$ & 25 Meter Level \\
\hline $60 M$ & 60 Meter Level \\
\hline $100 \mathrm{~N}$ & $100 \mathrm{~N}$ Area \\
\hline $6 \mathrm{~T}$ & 600 Area Tower (HMS) \\
\hline $200 W$ & 200 West Area \\
\hline ARMY & Army Loop Road \\
\hline AT & Dry Bulb Temperature \\
\hline $\mathrm{DP}$ & Dew Point Temperature \\
\hline DT & Delta-Temperature $(60 \mathrm{~m}-10 \mathrm{~m})$ \\
\hline EDNA & old Hanford Townsite \\
\hline EOC & Emergency Operation Center \\
\hline FRNK & Franklin County \\
\hline FFTF & Fast Flux Testing Facility \\
\hline
\end{tabular}


Key To Abbreviations In The Alpha/Numeric Identification (Cont'd.)

Abbreviation

GABL

GBLW

L01-L20

MN

MN24

$M X$

MX24

PROS

PASC

$\mathrm{RICH}$

RING

RF

RMTN

RSPG

SAGE

SD

$S R$

WAHL

WD

WPPS

WS

YAKB

RT

ST

VERN
Description

Gable Mountain Top

Gable Mountain West Side

Level 1 through Level 20

Min imum

24-hour Minimum

Maximum

24-hour Maximum

Prosser Barricade

Pasco Airport

Richland Airport

Ringold

Precipitation

Rattlesnake Mountain

Rattlesnake Spring

Sage Hill

Standard Deviation

Solar Radiation

Walukee Slope

Wind Direction

WPPSS 2

Wind Speed

Yakima Barricade

River Temperature

Soil Temperature

Vernita Bridge 
SENSOR NUMERIC AND ALPHA/NUMERIC IDENTIFICATIOH

\begin{tabular}{cl}
$\begin{array}{c}\text { Numeric } \\
\text { Identification }\end{array}$ & $\begin{array}{l}\text { Alpha/Numeric } \\
\text { Identification }\end{array}$ \\
\cline { 2 - 2 } 1 & \\
2 & WS-6T-7F \\
3 & WS-6T-30F \\
4 & WS-6T-50F \\
5 & WS-6T-50SEF \\
6 & WS-6T-100F \\
7 & WS-6T-200F \\
8 & WS-6T-300F \\
9 & WS-6T-400F \\
10 & AT-6T-30F \\
11 & AT-6T-50F \\
12 & AT-6T-100F \\
13 & AT-6T-300F \\
14 & WD-GABL \\
15 & AT-6T-250F \\
16 & AT-6T-400F \\
17 & AT-6T-200F \\
18 & WD-6T-7F \\
19 & WD-6T-30F \\
20 & WD-6T-50F \\
21 & WD-6T-50SEF \\
22 & WD-6T-200F \\
23 & WD-6T-100F \\
24 & WD-6T-300F \\
25 & WD-6T-400F \\
26 & NOT USED \\
27 & SR-6T \\
28 & WD-6D-L01M \\
29 & WD-6D-L02M \\
& WS-PROS \\
& \\
19 &
\end{tabular}

B.3 
Sensor Numeric And Alpha/Numeric Identification (Cont'd.)

\section{Numeric}

Identification

30

31

32

33

34

35

36

37

38

39

40

41

42

43

44

45

46

47

48

49

50

51

52

53

54

55

56

57

58

59
Alpha/Numeric

Identification

WS-EOC

WS-ARMY

WS-RSPG

WS-EDNA

WS-200E

WS-200W

WS-WAHL

DP-300A

WS-YAKB

WS-1D-L01M

WS-WYEB

WS-3D-L01M

WS-WPPS

WS-FRNK

WS-GABL

WS-RING

WS-RICH

WS-SAGE

WS-RMTN

MX-WS-100A-10M

WS-PSC

WS-6D-LO1M

WS-6D-LO2M

WS-6D-L03M

WS-6D-L04M

WS-6D-LO5M

WS-60-LO6M

WS-6D-L07M

WS-6D-LOBM

WS-6D-LO9M 
Sensor Numeric And Alpha/Numeric Identification (Cont'd.)

\begin{tabular}{cc}
$\begin{array}{c}\text { Numeric } \\
\text { Identification }\end{array}$ & $\begin{array}{c}\text { Alpha/Numeric } \\
\text { Identification }\end{array}$ \\
\cline { 2 - 2 } 60 & WS-6D-L10M \\
61 & WS-6D-L11M \\
62 & WS-6D-L12M \\
63 & WS-6D-L13M \\
64 & WS-6D-L14M \\
65 & WS-6D-L15M \\
66 & WS-6D-L16M \\
67 & WS-6D-L17M \\
68 & WS-6D-L18M \\
69 & WS-6D-L19M \\
70 & WD-6D-L03M \\
71 & WD-6D-L04M \\
72 & WD-6D-L05M \\
73 & WD-6D-L06M \\
74 & WD-6D-L07M \\
75 & WD-6D-L08M \\
76 & WD-6D-L09M \\
77 & WD-6D-L10M \\
78 & WD-6D-L11M \\
79 & WD-6D-L12M \\
80 & WS-4D-L01M \\
81 & WD-4D-LD1M \\
82 & WS-4D-L02M \\
83 & WS-4D-L03M \\
84 & WS-4D-L04M \\
85 & WS-4D-L05M \\
86 & WS-4D-L06M \\
87 & WS-4D-L07M \\
88 & WD-4D-L02M \\
89 & WD-40-L03M
\end{tabular}


Sensor Numeric And Alpha/Numeric Identification (Cont'd.)

\section{Numeric}

Identification

90

91

92

93

94

95

96

97

98

99

100

101

102

103

104

105

106

107

108

109

110

111

112

113

114

115

116

117

118

119
Alpha/Numeric Identification

WD-4D-LO4M

WD-4D-LO5M

WD-4D-LO6M

WS-100F

WS-GBLW

WD-GBLW

WS-100F

WS-FFTF-60M

WS-FFTF-25M

WS-FFTF-10M

AT-FFTF-60M

WD-FFTF-60M

WD-FFTF-25M

WD-FFTF-10M

AT-FFTF-10M

AT-FFTF-2M

SD-WS-FFTF-60M

SD-WS-FFTF-25M

SD-WS-FFTF-10M

SD-WD-FFTF-60M

SD-WD-FFTF-25M

SD-WD-FFTF-10M

DT-FFTF

DP-FFTF

WS-300A-10M

WD-300A-25M

WD-300A-60M

WD-300A-10M

WS-3D-LO2M

WS-3D-LO3M 


\begin{tabular}{|c|c|}
\hline $\begin{array}{c}\text { Numeric } \\
\text { Identification } \\
\end{array}$ & $\begin{array}{l}\text { Alpha/Numeric } \\
\text { Identification }\end{array}$ \\
\hline 120 & WS-3D-L04M \\
\hline 121 & WS-3D-L05M \\
\hline 122 & WD-1D-LDIM \\
\hline 123 & WD-3D-LD1M \\
\hline 124 & WD-3D-LO2M \\
\hline 125 & WD-3D-L03M \\
\hline 126 & WD-3D-LD4M \\
\hline 127 & WD-3D-L05M \\
\hline 128 & WD-3D-LO6M \\
\hline 129 & WD-3D-L07M \\
\hline 130 & WD-3D-L08M \\
\hline 131 & WD-3D-L09M \\
\hline 132 & WS-100A-10M \\
\hline 133 & $W S-100 A-25 M$ \\
\hline 134 & WS-100A-60M \\
\hline 135 & WS-300A-25M \\
\hline 136 & $W S-3 D O A-60 M$ \\
\hline 137 & $W D-100 A-10 M$ \\
\hline 138 & WD-100A-25M \\
\hline 139 & WD-100A-60M \\
\hline 140 & AT $-100 A-2 M$ \\
\hline 141 & AT-100A-10M \\
\hline 142 & AT-10DA-60M \\
\hline 143 & AT-30DA-2M \\
\hline 144 & AT-30DA-1DM \\
\hline 145 & AT-300A-6DM \\
\hline 146 & SD-WS-10DA-10M \\
\hline 147 & SD-WS-100A-25M \\
\hline 148 & SD-WS-100A-60M \\
\hline 149 & SD-WS-300A-10M \\
\hline
\end{tabular}


Sensor Numeric And Alpha/Numeric Identification (Cont'd.)

\begin{tabular}{cl}
$\begin{array}{c}\text { Numeric } \\
\text { Identification }\end{array}$ & $\begin{array}{c}\text { Alpha/Numeric } \\
\text { Identification }\end{array}$ \\
\cline { 2 - 2 } 150 & SD-WS-300A-25M \\
151 & SD-WS-100A-60M \\
152 & SD-WS-100A-10M \\
153 & SD-WD-100A-25M \\
154 & SD-WD-100A-60M \\
155 & SD-WD-300A-10M \\
156 & SD-WD-300A-25M \\
157 & SD-WD-300A-60M \\
158 & DT-100A \\
159 & DT-300A \\
160 & DP-1DOA \\
161 & WD-3D-L1DM \\
162 & WD-3D-L11M \\
163 & WD-3D-L12M \\
164 & WD-3D-L13M \\
165 & WD-3D-L14M \\
166 & WD-3D-L15M \\
167 & WD-3D-L16M \\
168 & WS-3D-L06M \\
169 & WS-3D-L07M \\
170 & WS-3D-L08M \\
171 & WS-3D-LO9M \\
172 & WD-3D-L17M \\
173 & WD-3D-L18M \\
174 & WD-3D-L19M \\
175 & WD-3D-L2OM \\
176 & WS-3D-L10M \\
177 & WS-3D-L11M \\
178 & WS-3D-L12M \\
179 & WS-3D-L13M \\
& \\
\hline 169 &
\end{tabular}

B. 8 


\begin{tabular}{|c|c|}
\hline $\begin{array}{c}\text { Numeric } \\
\text { Identification }\end{array}$ & $\begin{array}{l}\text { Alpha/Numeric } \\
\text { Identification }\end{array}$ \\
\hline 180 & WS-3D-L14M \\
\hline 181 & WS-3D-L15M \\
\hline 182 & WS-3D-L16M \\
\hline 183 & WS-3D-L17M \\
\hline 184 & WS-3D-L18M \\
\hline 185 & WS-3D-L19M \\
\hline 186 & WS-3D-L2OM \\
\hline 187 & WS-1D-L02M \\
\hline 188 & WS-1D-L03M \\
\hline 189 & WS-1D-L04M \\
\hline 190 & WS-1D-L05M \\
\hline 191 & WS-1D-L06M \\
\hline 192 & WS-1D-LD7M \\
\hline 193 & WS-1D-LDBM \\
\hline 194 & WS-1D-L09M \\
\hline 195 & WS-1D-L10M \\
\hline 196 & WS-6D-L2DM \\
\hline 197 & WD-6D-L13M \\
\hline 198 & WD-6D-L14M \\
\hline 199 & WD-6D-L15M \\
\hline 200 & WD-6D-L16M \\
\hline 201 & WD-6D-L17M \\
\hline 202 & WD-6D-L18M \\
\hline 203 & WD-6D-L19M \\
\hline 204 & $W D-6 D-L 20 M$ \\
\hline 205 & WS-1D-L11M \\
\hline 206 & WS-1D-L12M \\
\hline 207 & WS-1D-L13M \\
\hline 208 & WS-1D-L14M \\
\hline 209 & WS-1D-L15M \\
\hline
\end{tabular}




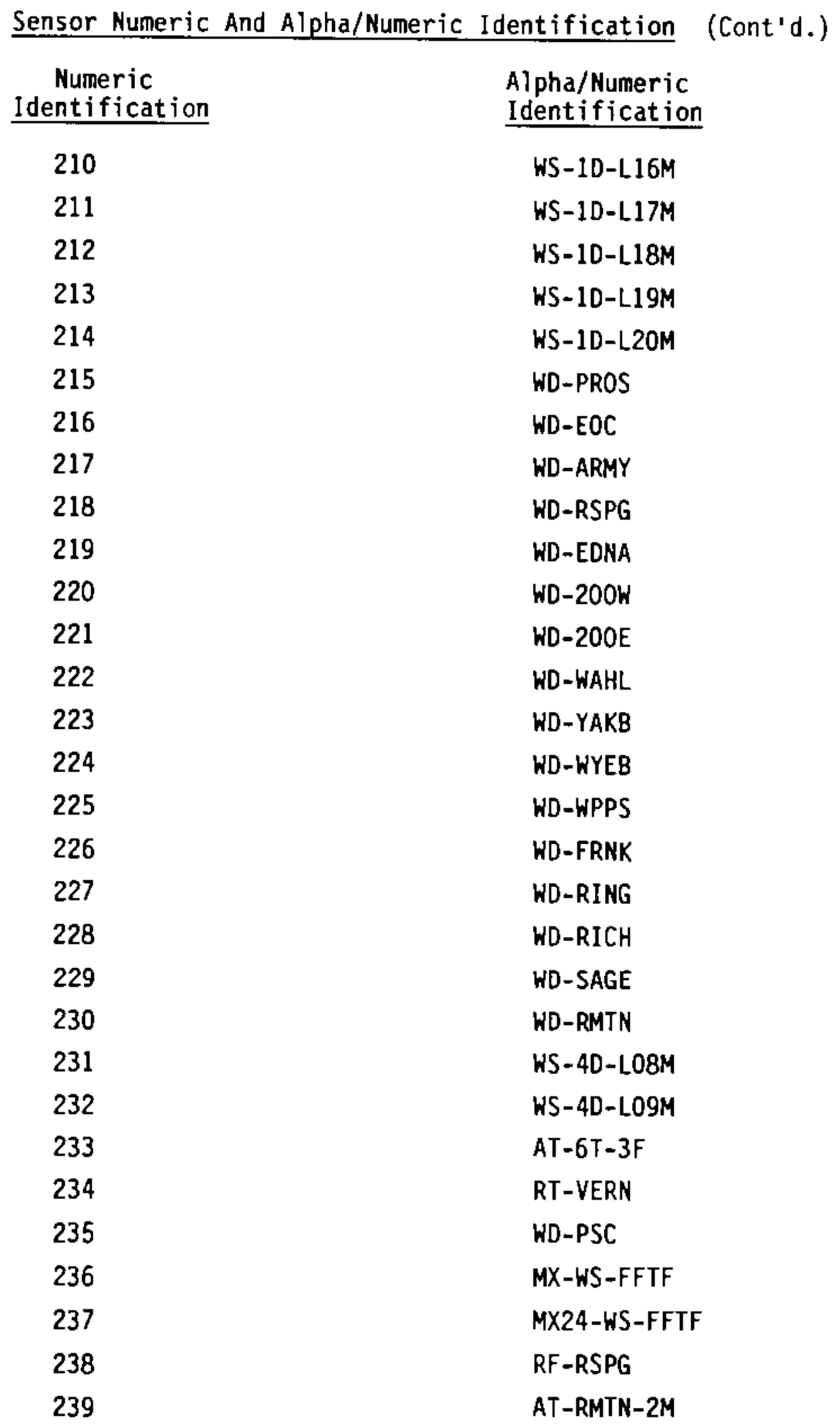




\begin{tabular}{|c|c|}
\hline $\begin{array}{c}\text { Numeric } \\
\text { Identification } \\
\end{array}$ & $\begin{array}{l}\text { Alpha/Numeric } \\
\text { Identification }\end{array}$ \\
\hline 240 & NOT USED \\
\hline 241 & $A T-E O C-2 M$ \\
\hline 242 & $M X-A T-E O C$ \\
\hline 243 & $M \times 24-W S-300 A$ \\
\hline 244 & $M X-W S-300 A-10 M$ \\
\hline 245 & SD-WD-RMTN-1OM \\
\hline 246 & $A T-R S P G-2 M$ \\
\hline 247 & MX24-WS-100N \\
\hline 248 & MX24-WS-GBLW \\
\hline 249 & $M \times 24-W S-100 F$ \\
\hline 250 & $M X-W S-G B L W$ \\
\hline 251 & $M X-W S-100 F$ \\
\hline 252 & MX-AT-RMTN \\
\hline 253 & MN-AT-RMTN \\
\hline 254 & $M X-W S-M T$ \\
\hline 255 & $M X-W S-50 F T$ \\
\hline 256 & $M X-A T-F F T F$ \\
\hline 257 & $M X-A T-300 A$ \\
\hline 258 & $M X-A T-100 N$ \\
\hline 259 & $M N-A T-100 N$ \\
\hline 260 & MN-AT-300A \\
\hline 261 & $M N-A T-F F T F$ \\
\hline 262 & $M N-A T-M T$ \\
\hline 263 & $M X-A T-M T$ \\
\hline 264 & NOT USED \\
\hline 265 & NOT USED \\
\hline 266 & MX24-AT-HMS \\
\hline 267 & MN24-AT-HMS \\
\hline 268 & MX-WS-RMTN \\
\hline 269 & MX24-WS-RMTN \\
\hline
\end{tabular}


Sensor Numeric And Alpha/Numeric Identification (Cont'd.)

\begin{tabular}{cl}
$\begin{array}{c}\text { Numeric } \\
\text { Identification }\end{array}$ & $\begin{array}{l}\text { Alpha/Numeric } \\
\text { Identification }\end{array}$ \\
\hline 270 & MX-WS-200FT \\
271 & MX-WS-400FT \\
272 & MX-AT-RSPG \\
273 & MN-AT-RSPG \\
274 & RF-YAKB \\
275 & NOT USED \\
276 & RF-PASC \\
277 & RF-RICH \\
278 & AT-YAKB-2M \\
279 & MX-AT-YAKB \\
280 & MN-AT-YAKB \\
281 & AT-EDNA-2M \\
282 & AT-20OW-2M \\
283 & AT-WAHL-2M \\
284 & AT-WYEB-2M \\
285 & AT-GABL-2M \\
286 & AT-WPPS-2M \\
287 & MX-AT-EDNA \\
288 & MX-AT-200W \\
289 & AT-SAGE-2M \\
290 & MX-AT-WYEB \\
291 & MX-AT-GABL \\
292 & MN-AT-EDNA \\
293 & MN-AT-2DOW \\
294 & MX-AT-SAGE \\
295 & MN-AT-WYEB \\
296 & MN-AT-GABL \\
297 & AT-ARMY-2M \\
298 & MN-AT-ARMY \\
299 & MX-AT-ARMY
\end{tabular}


Sensor Numeric And Alpha/Numeric Identification (Cont'd.)

\begin{tabular}{cl}
$\begin{array}{c}\text { Numeric } \\
\text { Identification }\end{array}$ & $\begin{array}{c}\text { Alpha/Numeric } \\
\text { Identification }\end{array}$ \\
\cline { 2 - 3 } 300 & MN-AT-WAHL \\
301 & MX-AT-WAHL \\
302 & MX-AT-WPPS \\
303 & MN-AT-WPPS \\
304 & MN-AT-SAGE \\
305 & MX-AT-RING \\
306 & MX-AT-FRNK \\
307 & MN-AT-FRNK \\
308 & MN-AT-RING \\
309 & AT-FRNK-2M \\
310 & AT-RING-2M \\
311 & MX24-AT-RMTN \\
312 & MN24-AT-RMTN \\
313 & MN24-AT-ARMY \\
314 & MN24-AT-RSPG \\
315 & MN24-AT-EDNA \\
316 & MN24-AT-200W \\
317 & MN24-AT-WAHL \\
318 & MN24-AT-YAKB \\
319 & MN24-AT-WYEB \\
320 & MN24-AT-WPPS \\
321 & MN24-AT-FRNK \\
322 & MN24-AT-GABL \\
323 & MN24-AT-RING \\
324 & MX24-AT-ARMY \\
325 & MX24-AT-RSPG \\
326 & MX24-AT-EDNA \\
327 & MX24-AT-20DW \\
328 & MX24-AT-WAHL \\
329 & MX24-AT-YAKB
\end{tabular}


Sensor Numeric And Alpha/Numeric Identification (Cont'd.)

\begin{tabular}{cl}
$\begin{array}{c}\text { Numeric } \\
\text { Identification }\end{array}$ & $\begin{array}{l}\text { Alpha/Numeric } \\
\text { Identification }\end{array}$ \\
\hline 330 & MX24-AT-WYEB \\
331 & MX24-AT-WPPS \\
332 & MX24-AT-FRNK \\
333 & MX24-AT-GABL \\
334 & MX24-AT-RING \\
335 & MX24-AT-SAGE \\
336 & MN-AT-EOC \\
337 & MX24-AT-EOC \\
338 & MN24-AT-EOC \\
339 & ST-6T-1/2IN \\
340 & ST-6T-15IN \\
341 & ST-6T-36IN \\
342 & AT-200E-2M \\
343 & MX24-AT-200E \\
344 & MN24-AT-200E \\
345 & MN-AT-200E \\
346 & AT-PROS-2M \\
347 & AT-RICH-2M \\
348 & AT-GBLW-2M \\
349 & AT-100F-2M \\
350 & MX-AT-PROS \\
351 & MX-AT-200E \\
352 & MX-AT-RICH \\
353 & MX-AT-GBLW \\
354 & MX-AT-100F \\
355 & MN-AT-PROS \\
356 & MN-AT-RICH \\
357 & MN-AT-GBLW \\
358 & MN-AT-100F \\
359 & MX24-AT-PROS
\end{tabular}




\begin{tabular}{|c|c|}
\hline $\begin{array}{c}\text { Numeric } \\
\text { Identification }\end{array}$ & $\begin{array}{l}\text { Alpha/Numeric } \\
\text { Identification }\end{array}$ \\
\hline 360 & MX24-AT-RICH \\
\hline 361 & $M \times 24-A T-G B L W$ \\
\hline 362 & $M \times 24-A T-100 F$ \\
\hline 363 & MN24-AT-PROS \\
\hline 364 & MN24-AT-RICH \\
\hline 365 & MN24-AT-SAGE \\
\hline 366 & MN24-AT-GBLH \\
\hline 367 & MN24-AT-300A \\
\hline 368 & MN24-AT-FFTF \\
\hline 369 & MN24-AT-100A \\
\hline 370 & $M \times 24-A T-100 A$ \\
\hline 371 & $M \times 24-A T-300 A$ \\
\hline 372 & MX24-AT-FFTF \\
\hline 373 & SD-WS-GBLW-1OM \\
\hline 374 & SD-WS-100F-10M \\
\hline 375 & SD-WD-100F-10M \\
\hline 376 & SD-WD-GBLW-1OM \\
\hline 377 & MN24-AT-100F \\
\hline 378 & $M X-W S-P A S C$ \\
\hline 379 & MX24-WS-PASC \\
\hline 380 & AT-PASC-2M \\
\hline 381 & MN-AT-PASC \\
\hline 382 & MX-AT-PASC \\
\hline 383 & MN24-AT-PASC \\
\hline 384 & MX24-AT-PASC \\
\hline 385 & NOT USED \\
\hline 386 & WD-VERN \\
\hline 387 & WS-VERN \\
\hline 388 & MX-WS-VERN \\
\hline 389 & MX-RT-VERN \\
\hline
\end{tabular}

B. 15 
Sensor Numeric And Alpha/Numeric Identification (Cont'd.)

\begin{tabular}{c}
$\begin{array}{c}\text { Numeric } \\
\text { Identification }\end{array}$ \\
\hline 390 \\
391 \\
392 \\
393 \\
394 \\
395 \\
396 \\
397
\end{tabular}

Alpha/Numeric

Identification

MN-RT-VERN

AT-VERN-2M

$M X-A T-V E R N$

MN-AT-VERN

MX24-AT-VERN

MN24-AT-VERN

MX24-RT-VERN

MN24-RT-VERN 


\section{DISTRIBUTION}

No. of

Copies

OFFSITE

10 DOE/Office of Scientific and Technical Information

ONSITE

DOE Richland Operations office

J. J. Sutey

39 Pacific Northwest Laboratory

G. L. Andrews (15)

K. A. Borgeson

K. L. Feuerbacher

0. P. Gifford

C. S. Glantz

M. J. Graham

J. M. Hales

P. C. Hays

D. J. Hoit ink

W. D. McCormack

D. J. Newl and

W. T. Pennell

P. J. Perrault

E. R. Preston

J. V. Ramsdell

G. N. Reinecke

M. N. Schwartz

L. L. Wendell

Publishing Coordination (2)

Technical Report Files (5) 
$\because$ 